\title{
Evaluation of ECMWF water vapour fields by airborne differential absorption lidar measurements: a case study between Brazil and Europe
}

\author{
H. Flentje ${ }^{1}$, A. Dörnbrack ${ }^{2}$, A. Fix ${ }^{2}$, G. Ehret ${ }^{2}$, and E. Hólm ${ }^{3}$ \\ ${ }^{1}$ Deutscher Wetterdienst, Hohenpeißenberg, Germany \\ ${ }^{2}$ DLR Institut für Physik der Atmosphäre, Oberpfaffenhofen, Germany \\ ${ }^{3}$ European Centre For Medium Range Weather Forecasts, Reading, UK \\ Received: 8 March 2007 - Published in Atmos. Chem. Phys. Discuss.: 30 March 2007 \\ Revised: 8 August 2007 - Accepted: 9 September 2007 - Published: 1 October 2007
}

\begin{abstract}
Three extended airborne Differential Absorption Lidar (DIAL) sections of tropospheric water vapour across the tropical and sub-tropical Atlantic in March 2004 are compared to short-term forecasts of the European Centre for Medium Range Weather Forecasts (ECMWF). The humidity fields between $28^{\circ} \mathrm{S}$ and $36^{\circ} \mathrm{N}$ exhibit large inter air-mass gradients and reflect typical transport patterns of low- and mid-latitudes like convection (e.g. Hadley circulation), subsidence and baroclinic development with stratospheric intrusion. These processes re-distribute water vapour vertically such that locations with extraordinary dry/moist air-masses are observed in the lower/upper troposphere, respectively. The mixing ratios range over 3 orders of magnitude. Backtrajectories are used to trace and characterize the observed air-masses.

Overall, the observed water vapour distributions are largely reproduced by the short-term forecasts at $0.25^{\circ}$ resolution (T799/L91), the correlation ranges from 0.69 to 0.92 . Locally, large differences occur due to comparably small spatial shifts in presence of strong gradients. Systematic deviations are found associated with specific atmospheric domains. The planetary boundary layer in the forecast is too moist and to shallow. Convective transport of humidity to the middle and upper troposphere tends to be overestimated. Potential impacts arising from data assimilation and model physics are considered. The matching of air-mass boundaries (transport) is discussed with repect to scales and the representativity of the 2-D sections for the 3-D humidity field. The normalized bias of the model with respect to the observations is $6 \%, 11 \%$ and $0 \%$ (moist model biases) for the three along-flight sections, whereby however the lowest levels are excluded.
\end{abstract}

Correspondence to: $\mathrm{H}$. Flentje

(harald.flentje@dwd.de)

\section{Introduction}

Atmospheric water vapour (WV) as the primary greenhouse gas (Manabe and Weatherald, 1967; Shine and Sinha, 1991) plays a key role in the global climate system (Chahine, 1992). The latent heat transformations associated with its phase changes alter the atmospheric stability, control the cloud formation (e.g. Kiehl and Trenberth, 1997; Koop et al., 2004; Kärcher, 2004) and the evolution of weather systems. Relative humidity regulates radiative and chemical properties of aerosols (Charlson and Heintzenberg, 1994; Pruppacher and Klett, 1997) and as the prime source of atmospheric hydroxyl radicals (Rohrer and Berresheim, 2006), WV plays a key role in removing both, particles and trace gases from the atmosphere. In spite of its low concentration in the stratosphere, WV alters the radiation balance (Forster and Shine, 1999) and controls the formation of particles, e.g. affecting ozone depletion (Kirk-Davidoff et al., 1999). Thus, accurate analyses of water vapour are essential not only for numerical weather forecast but also for atmospheric process studies, climate modelling, trend analyses and the understanding of the hydrological cycle.

In recent years, climate research centres and weather services have extensively developed the humidity analysis. In particular, the European Centre for Medium Range Weather Forecasts (ECMWF) derived an improved formulation of the background error covariance model for humidity (Hólm et al., 2002) and introduced data from several additional satellite instruments (Moreau et al., 2003; Andersson et al., 2006), in both geostationary (METEOSAT and GOES) and polar orbits (AMSU-B, AIRS and HIRS). The satellite data are assimilated directly as radiances (Bauer, 2002) and provide very good coverage over the oceans, with gaps in cloudy and precipitating regions. The geostationary radiances and some of the higher-peaking channels of AIRS, HIRS and

Published by Copernicus Publications on behalf of the European Geosciences Union. 
AMSU-B are also used over land. Radiosonde dew-point temperature observations are used at all reported levels below $100 \mathrm{hPa}$ from the types RS80 and RS90/92 or below $300 \mathrm{hPa}$ from all others due to temperature induced limitations (Nash, 2002, Leiterer et al., 2005). Surface dew-point humidity data (SYNOP 2-metre) are only used over land and during daytime. Both radiosonde and surface data are not corrected for biases. About 1 million humidity data are used every $12 \mathrm{~h}$. In addition to advanced data assimilation, new parameterizations of moist physics (Tompkins et al., 2004) and supersaturation (Tompkins et al., 2007 - not yet included in our version) have been introduced. With the ECMWF 4D-Var assimilation system the specific impact of different humidity data extends to forecasts in the medium range (5-6 days), not only for precipitation and water vapour but also for other prognostic variables like geopotential, wind and temperature (Andersson et al., 2004, 2006). As the analysis mostly adds only a few percent to the background fields of the assimilation scheme (increments are $<5 \%$ of the fields in general), humidity observations should be as little biased as possible. However, most assimilated humidity observing systems currently exceed an absolute calibration of $10 \%$, an error which propagates to the total analysis and forecast errors.

In this paper we investigate the accuracy of short-term ECMWF humidity forecasts (which provide almost the same accuracy as the analysis) by a detailed comparison with longrange airborne Differential Absorption Lidar (DIAL) observations. DIAL $\mathrm{H}_{2} \mathrm{O}$ observations have a low bias which is determined by the accuracy of the utilized $\mathrm{H}_{2} \mathrm{O}$ spectral absorption cross sections and are little sensitive to atmospheric conditions (Poberaj et al., 2002). A promising skill was found for operational ECMWF analyses and mesoscale numerical simulations in reproducing DIAL observations along the North Atlantic storm track region in May/June 2002 (Flentje et al., 2005). Here we extend this study to water vapour observations over Brazil and the tropical and sub-tropical Atlantic Ocean between Brazil and Europe in mid March 2004. To this end, short-term ECMWF forecasts at a spectral resolution of T799/L91 and ECMWF-based backward trajectories are employed.

The following section outlines the experiment, the DIAL and analysis tools, Sect. 3 discusses the matching of the measurements and the ECWMF fields in the context of the meteorological conditions. In Sect. 4, conclusions from the skill and biases of the ECMWF water vapour forecasts are drawn, a summary is given in Sect. 5 .

\section{DIAL measurements and models}

Water vapour and the particle backscatter ratio were measured by an airborne Differential Absorption Lidar (DIAL) during the international TROCCINOX campaign (www.pa. op.dlr.de/troccinox). There three long-range flights were performed, one on 10 March 2004 and two consecutive transfer flights on 14 March 2004 with a total distance of about 7000 $\mathrm{km}$. The flight on 10 March went from SE Brazil $\left(22^{\circ} \mathrm{S}\right.$, $47^{\circ} \mathrm{W}$ ) south toward the Atlantic Ocean and returned at $28^{\circ} \mathrm{S}$ (Fig. 1). On 14 March the Atlantic Ocean was crossed from Fernando de Naronha, Brazil $\left(5^{\circ} \mathrm{S}, 36^{\circ} \mathrm{W}\right)$ to South Spain $\left(36.2^{\circ} \mathrm{N}, 6^{\circ} \mathrm{W}\right)$ with stopover in Sal (Cape Verde Islands). The DIAL was installed nadir viewing onboard a Falcon 20E research jet aircraft with about $3500 \mathrm{~km}$ endurance and a ceiling altitude of about $13 \mathrm{~km}$ (www.dlr.de/fb/). Air traffic control prescribed a cruising altitude around $11 \mathrm{~km}$ thus the troposphere could be profiled from the ground up to $\sim 10 \mathrm{~km}$ height.

\section{$2.1 \mathrm{H}_{2} \mathrm{O}-\mathrm{DIAL}$}

As described by Ehret et al. (1999) and Poberaj et al. (2002), the DLR $\mathrm{H}_{2} \mathrm{O}$-DIAL transmitter is based on a Nd:YAG pumped, injection seeded KTP-OPO (Optical Parametric Oscillator). During TROCCINOX the DIAL was operated at $925 \mathrm{~nm}$ achieving a pulse energy of $18 \mathrm{~mJ}$. A spectral purity of more than $99.5 \%$ was mostly achieved during inflight operation which allows accurate calculation of the water vapour concentrations. The $925 \mathrm{~nm}$ spectral region fits for water vapour measurements from the planetary boundary layer (PBL) up to the upper troposphere with a resolution of about $500 \mathrm{~m}$ in the vertical and $2-3 \mathrm{~km}$ horizontally, however to match the horizontal resolution of the ECMWF fields the DIAL data are averaged over $25 \mathrm{~km}$ horizontally. In the nadir-viewing configuration the range-induced signal decrease is partly compensated by the increasing $\mathrm{H}_{2} \mathrm{O}-$ absorption in the lower troposphere. Only the range where the crossed optical depth remains below 0.9 (one way) is evaluated. Systematic errors are due to uncertainties in the water vapour absorption line cross section (estimated 5\%), laser spectral impurity (1-2\%), atmospheric temperature uncertainty $(<1 \%)$, and the Rayleigh-Doppler absorption line broadening $(<1.5 \%$ after correction). They sum up to about $5.5 \%$ in total. The random error of the DIAL measurements depends on the horizontal and vertical averaging of the individual shots. When the DIAL spatial resolution is degraded to that of the ECMWF fields, the random error remains below $10 \%$ even in dry regions. Aerosol properties are expressed as particle backscatter ratio, defined as the total (particle + molecular) backscatter coefficient $\beta_{\lambda}$ divided by the molecular backscatter coefficient $\operatorname{BSR}_{\lambda}=\left(\beta_{p, \lambda}+\beta_{m, \lambda}\right) / \beta_{m, \lambda}(\lambda$ denoting the wavelengths). The achievable aerosol spatial resolution virtually depends on the aerosol backscatter ratio and typically amounts to few $100 \mathrm{~m}$ horizontally and $\sim 50 \mathrm{~m}$ vertically.

\subsection{Short-term ECMWF forecasts}

The model water vapour fields are generated by shortterm high resolution forecasts from the latest analysis 
(a)

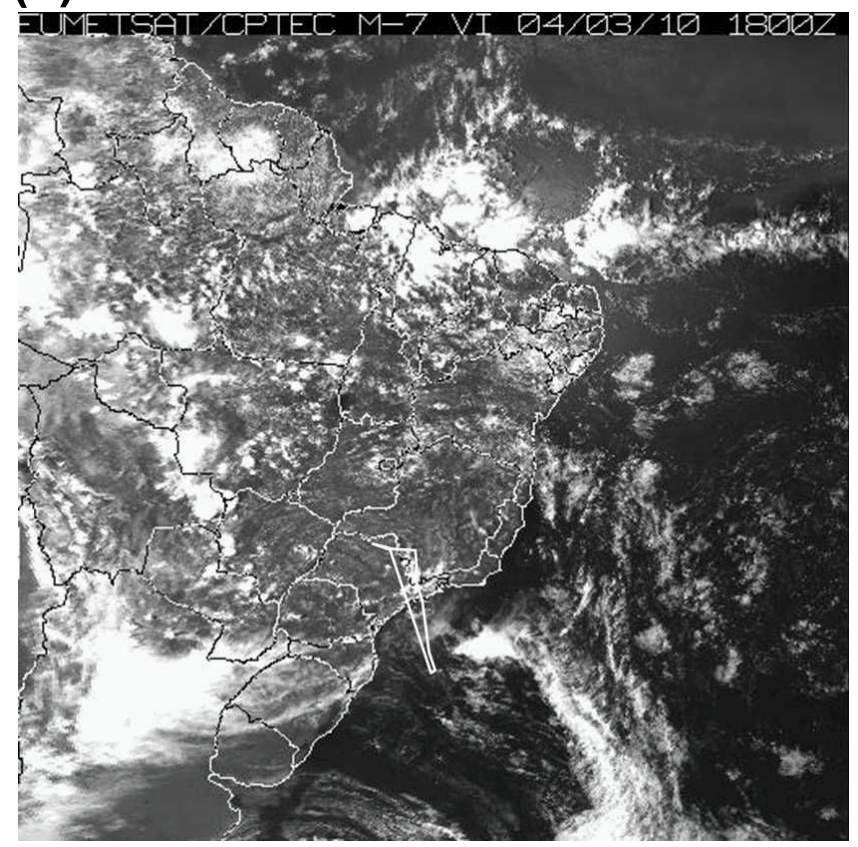

(b)

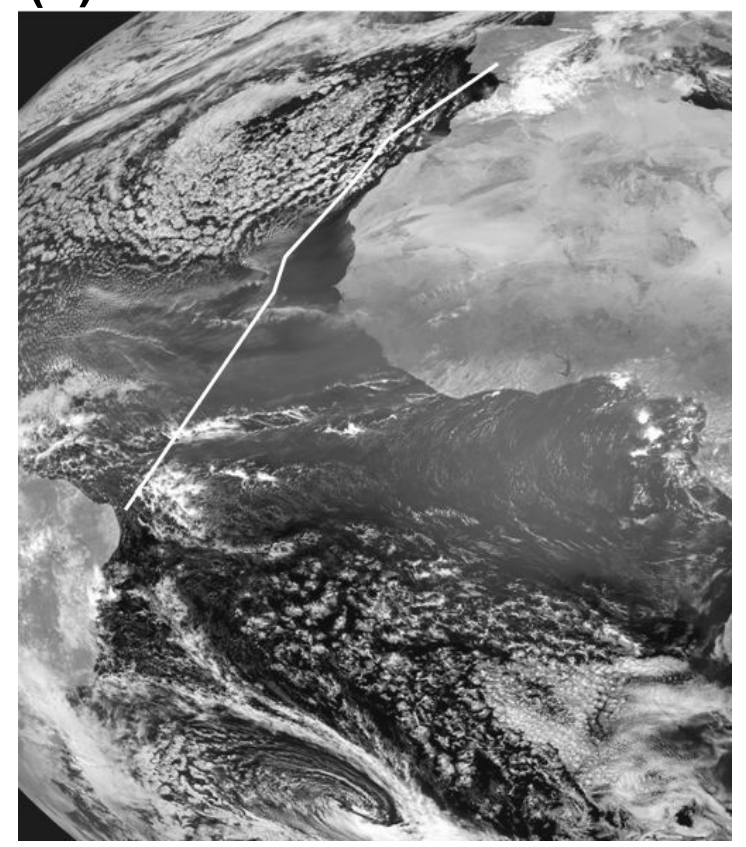

Fig. 1. METEOSAT-8 vis images with DIAL flight paths indicated by white lines: Left (a) from 10 March 2004, 18:00 UT and right (b) from 14 March 2004, 12:00 UT.

$\left(\mathrm{T} 799 / \mathrm{L}^{1}{ }^{1}\right)$ available before each flight segment and provide about the same accuracy as the analysis. The length of the forecast varies from 0 to $8 \mathrm{~h}$ from the latest analysis, which is available 6-hourly. When a flight segment went from e.g. 17:00 UT to 19:00 UT, the forecast starting from 12:00 UT was used for the whole segment to avoid jump in the middle of the segment associated with the analysis update. After the fields have been interpolated from their original reduced Gaussian grid to a regular lat-lon grid (which has little effect at low latitudes) the model output is written for every hour at $0.25^{\circ}$ resolution. Then the model profiles are interpolated linearly to the observation location, both in space and time (between nearest $1 \mathrm{~h}$ outputs). From the pressure, temperature and humidity at the model levels the geometrical altitude is integrated, since the DIAL data are based on aircraft GPS altitudes. The uncertainty induced by the model using an average orography height over the gridbox is reduced by averaging the lasers estimate of the surface height along track over the corresponding distance and matching model average with laser average. However, most parts of the tracks are over the ocean anyway.

\subsection{Back trajectories}

Backward trajectories are calculated with the Lagrangian Analysis Tool (LAGRANTO) software package developed at the ETH Zürich by Wernli and Davies (1997). They are

\footnotetext{
${ }^{1}$ http://www.ecmwf.int/products/data/technical/index.html
}

driven by 6-hourly ECMWF-analyses at T511/L60 spectral resolution and allow to follow the development of meteorological parameters along the flow - here we chose air temperature to indicate possible diabatic processes. Intercomparisons of LAGRANTO and other trajectory models e.g. by Stohl et al. (2001) report close agreement up to $48 \mathrm{~h}$, but depending on situation and altitude (better at higher levels) and on the coherence of the ensembles, trust can be given in the results for 5 and more days. In this paper, we show only representative 7-day back-trajectories from coherent ensembles to trace the origin of selected noteworthy features.

\section{Results}

\subsection{Meteorological conditions}

The $\mathrm{H}_{2} \mathrm{O}$-DIAL observations reflect dynamical features typical for the sub-tropical and tropical troposphere and may thus be regarded as representative for a wide range of low latitude conditions. The 10 March flight roughly runs along the upper ridge axis of a Bolivian high pressure system with a relatively high tropopause $(14 \mathrm{~km})$ and relatively low convective potential. Only near Sao Paolo $\left(23.5^{\circ} \mathrm{S}, 46.7^{\circ} \mathrm{W}\right)$ a mesoscale convective system (MCS) is formed as indicated by growing Cb-clouds in METEOSAT 8 VIS imagery (Fig. 1a). Over the Atlantic Ocean, the marine planetary boundary layer (PBL) is little convective and capped below $1 \mathrm{~km}$. The first flight on 14 March is a slant section through the Hadley cell. Initially 


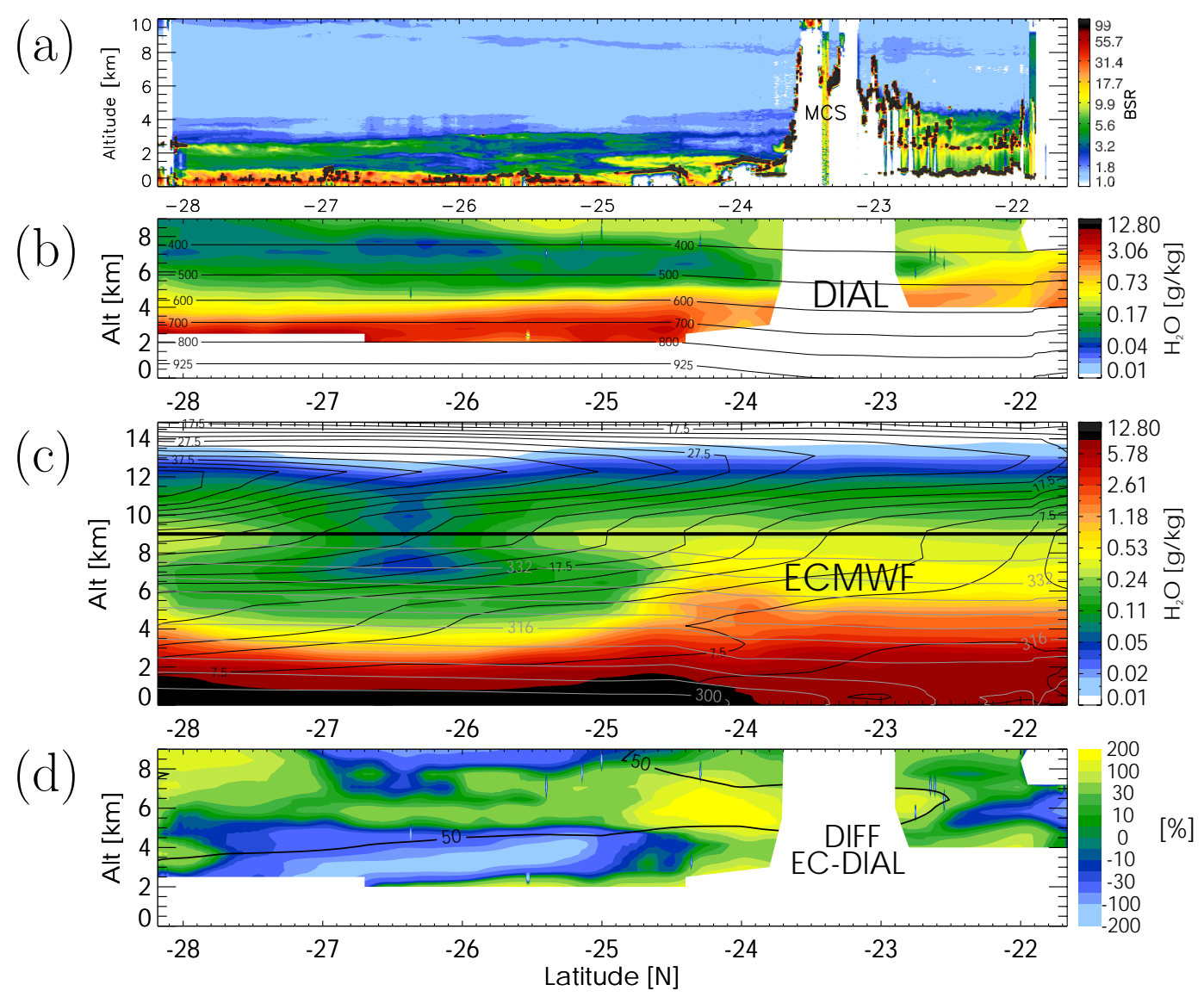

Fig. 2. Along-flight sections from 10 March 2004, 18:00-20:00 UT. (a) Backscatter ratio BSR at 1064 nm, (b) water vapour mixing ratio $(\mathrm{g} / \mathrm{kg})$ measured by DIAL $q_{\text {DIAL }}$ with contours of ECMWF pressure, (c) water vapour mixing $(\mathrm{g} / \mathrm{kg})$ ratio from ECMWF short-term forecasts

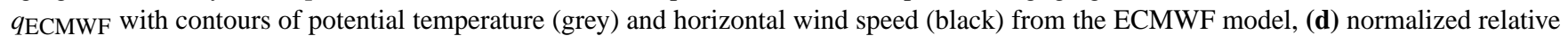
difference between ECMWF and DIAL $100\left(q_{\mathrm{ECMWF}}-q_{\mathrm{DIAL}}\right) /\left(q_{\mathrm{ECMWF}} / 2+q_{\mathrm{DIAL}} / 2\right)$ with contours of the development nonlinearity as described in Sect. $3\left(\left(q_{\mathrm{to}}+6 \mathrm{~h}+q_{\mathrm{to}}-6 \mathrm{~h}\right) / 2-q_{\mathrm{to}}\right) / q_{\mathrm{to}}$.

it crosses the intertropical convergence zone (ITCZ) which follows the NE coast of Brazil (Fig. 1b). Later on the cloudfree subtropical subsidence zone is entered. The second flight roughly follows the axis of a trough along the northwest African coast and finally enters a cyclone over Gibraltar. There the jet stream is crossed as indicated by a stratospheric intrusion reaching down to below $2 \mathrm{~km}$. Also in the METEOSAT 8 image a broad dust plume is evident as grey belt which spreads out westward from the African continent in the easterly low-level trade winds.

\subsection{Mesoscale convective system on 10 March 2004}

Figure 2a shows the along-flight section of particle backscatter ratio $\mathrm{BSR}_{1064}$ on 10 March (denoted F030310). The strongly scattering $\mathrm{Cb}$ clouds associated with the MCS centred around $23.5^{\circ} \mathrm{S}$ reach up above the flight level and shield the air below from DIAL measurement. Polluted air flowing southward from the continent (e.g. Sao Paolo plume at 24- $25^{\circ} \mathrm{S}$, below $1.5 \mathrm{~km}$ ) is found up to $3-4 \mathrm{~km}$ over the ocean with $\mathrm{BSR}_{1064} \approx 3-7$. Above $4 \mathrm{~km}(600 \mathrm{hPa})$ the wind turns from north to southeast and back-trajectories (not shown) circle the Bolivian anticyclone up till the tropopause. As shown by the water vapour distribution in Fig. $2 b$, the shear zone near $4 \mathrm{~km}$ separates humid air with water vapour mixing ratio $q>5 \mathrm{~g} / \mathrm{kg}$ below from dry free troposphere air with $q<0.2 \mathrm{~g} / \mathrm{kg}$ above. Deep convection inside the MCS injects humid air from lower levels to the upper troposphere (UT) and contributes to the humid air outflow downwind of the continent evident as a layer with $q \approx 0.5 \mathrm{~g} / \mathrm{kg}$ above $7 \mathrm{~km}$.

The corresponding ECMWF water vapour field is shown in Fig. 2c up to $15 \mathrm{~km}$, where the top of the DIAL section near $9 \mathrm{~km}$ is indicated by a thick black line. Overlaid contours of potential temperature (grey) and horizontal wind speed (black) indicate the absence of lower level fronts and the nearby jet stream in the south of the flight leg. The relative difference $100\left(q_{\mathrm{ECMWF}}-q_{\mathrm{DIAL}}\right) /\left(q_{\mathrm{ECMWF}} / 2+q_{\mathrm{DIAL}} / 2\right)$ 


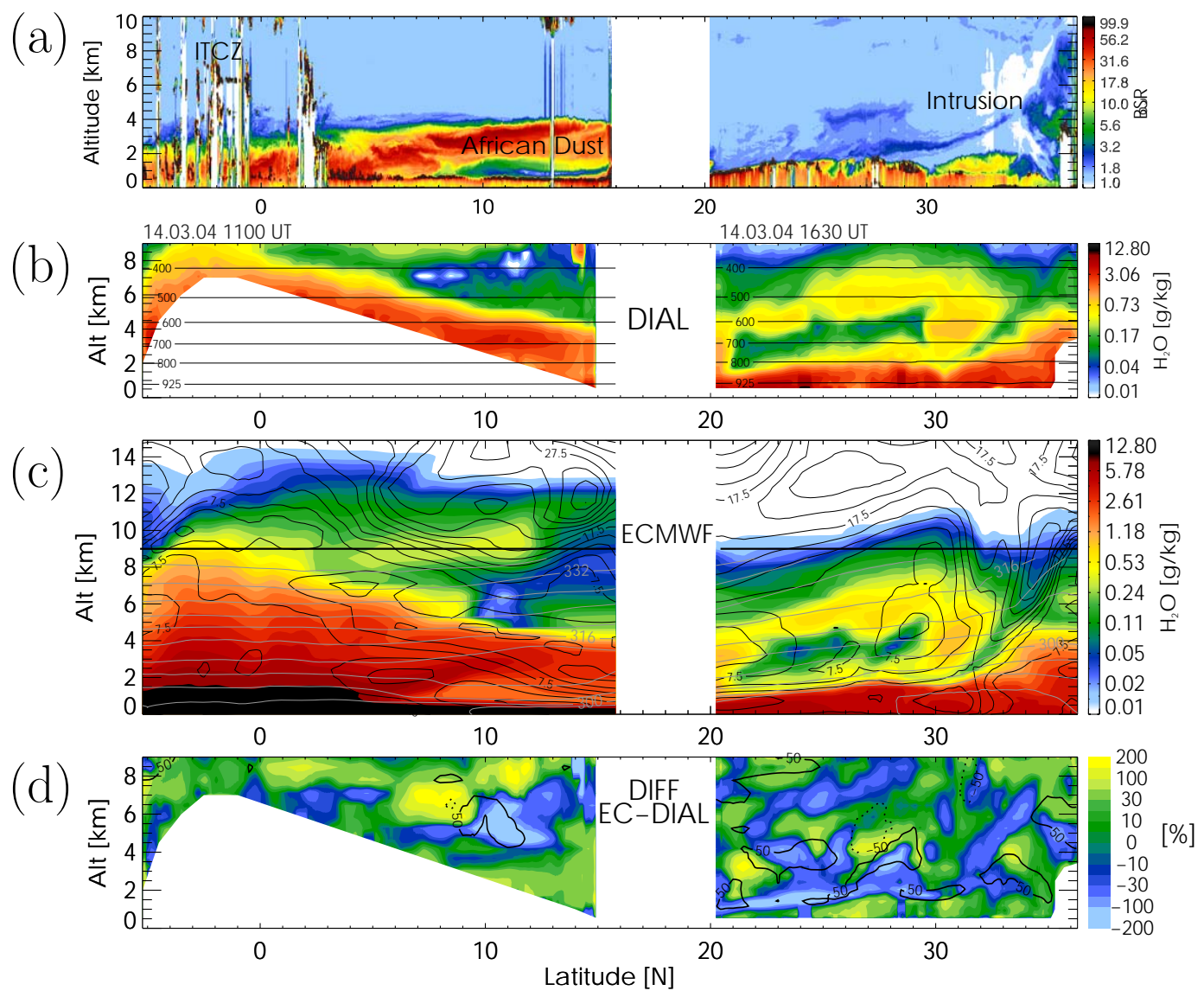

Fig. 3. As Fig. 2 but for DIAL flights on 14 March 2004, 11:00-14:00 UT ( $\left.5^{\circ} \mathrm{S}-15^{\circ} \mathrm{N}\right)$ and 16:30-19:00 UT $\left(20^{\circ} \mathrm{N}-36^{\circ} \mathrm{N}\right)$.

between the observed and forecasted (FC) water vapour mixing ratios is displayed in Fig. 2d. Dry deviations of the FC from the observations appear bluish, wet deviations green/yellow. Overlaid black contours are the nonlinearity of the 12-hourly q-development, defined as the difference between the initialization analysis $q_{\mathrm{to}}$ at time $t_{0}$ to the mean of previous and next nearest analysis, normalized to $q_{\mathrm{to}}\left(\left(q_{\mathrm{to}+6 \mathrm{~h}}+q_{\mathrm{to}-6 \mathrm{~h}}\right) / 2-q_{\mathrm{to}}\right) / q_{\mathrm{to}}$. This provides a measure of uncertainties due to the spatiotemporal interpolation, though these are minimized by the use of 1-hourly fields.

Overall, the observed humidity patterns are reproduced in the ECMWF fields (Fig. 2b-d). The largest dry deviation (of model with respect to observation) occurs at the top of the PBL which is nearly $1 \mathrm{~km}$ too flat in the model. The largest positive bias is found at mid-levels around the MCS, where the observed dry layer between convective in- and outflow is largely missing. As indicated by the black contours in Fig. 2d, the 12-hourly development is highly nonlinear (instable) in this region whereas little change is found in the development of the PBL. Another humidity uplift pattern indicated by the model in the south of the flight track only rudimentary shows up in the DIAL section. The lowest troposphere can not be evaluated since there the penetrable optical depth is exceeded.

\subsection{Hadley cell on 14 March 2004}

Figure 3 shows the along-flight sections of particle $\mathrm{BSR}_{1064}$ (panel 3a), water vapour mixing ratio $q$ from DIAL (panel $3 \mathrm{~b}$ ) and ECMWF (panel 3c) and the relative difference between model and DIAL (panel 3d) for the two 14 March flights, arranged as in Fig. 2. In the south section (F0303141) near the equator $\mathrm{Cb}$ clouds indicate the ITCZ (Fig. 3a note the biased cloud coverage as deep $\mathrm{Cb}$ are circled by the aircraft for security reasons). The African dust layer emerging in Fig. $1 b$ is initially (i.e. most easterly) detached from the PBL between 2 and $4 \mathrm{~km}$ and settles during westward transport. More than $1000 \mathrm{~km}$ to the west (near $8^{\circ} \mathrm{N}, 25^{\circ} \mathrm{W}$ ) it mixes into the PBL. The water vapour fields in Fig. 3b,c reflect the ITCZ convective transport of moist lower level air to the upper troposphere $(\sim 12 \mathrm{~km}$, cf. Fig. $3 \mathrm{c})$ and then to the north. Back-trajectories, colour coded by temperature, arriving in the flight section at $300 \mathrm{hPa}$ (Fig. 4 - "Hadley Cell") show that these air-masses are subject to the Hadley circulation and finally descend to the flight track. This circulation reflects in 3 features: a moist layer $(q>3 \mathrm{~g} / \mathrm{kg})$ declining from $\sim 9 \mathrm{~km}$ near the equator to $\sim 4 \mathrm{~km}$ at the end of the flight track at $15^{\circ} \mathrm{N}$; a moist layer $(q \approx 0.2-0.5 \mathrm{~g} / \mathrm{kg})$ at upper levels $(\sim 9 \mathrm{~km})$ reaching from the equator till $\sim 15^{\circ} \mathrm{N}$; 
Trajectories arriving at $300 \mathrm{hPa}$

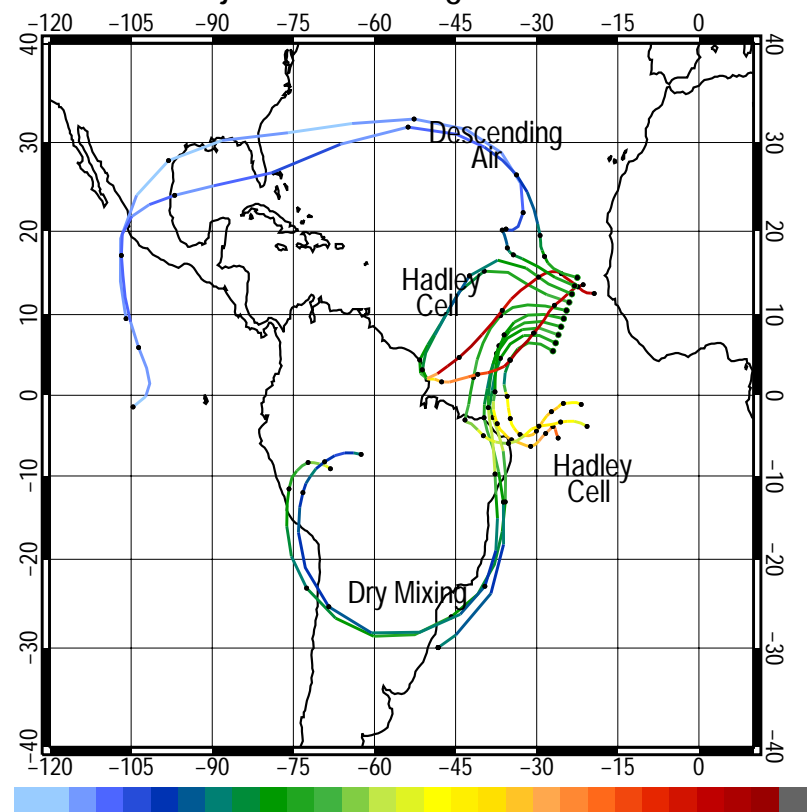

$203210217224231237244251258265272 \quad 279286293 \quad 300$

Fig. 4. Selected ECMWF 7-day backward trajectories arriving in the DIAL section at $300 \mathrm{hPa}$ on 14 March 2004, 12:00 UT. Colour coding with temperature indicates vertical transport.

a dry intermediate subsidence layer with $q<0.1 \mathrm{~g} / \mathrm{kg}$ in the mid-troposphere $(\sim 6-8 \mathrm{~km})$. The upper-level moist layer has a gap between $0^{\circ} \mathrm{N}$ and $5^{\circ} \mathrm{N}$ due to descending dry air from the Bolivian anticyclone reaching the flight section at $300 \mathrm{hPa}$ (Fig. 4 "Dry Mixing"). Figure 4 further shows that the very dry mid-layer air-mass descends and originates from higher latitudes ("Descending Air" in Fig. 4). It is interesting to note that the African dust layer has no signature in water vapour. The part below the $\mathrm{H}_{2} \mathrm{O}$ absorption line saturationthreshold is masked in Figs. $3 b$ and d.

Again the main features of the water vapour distribution along the flight path are reproduced by the ECMWF model. Figure $3 \mathrm{~d}$ shows that the dry intermediate layer in the FC is slightly too moist and does not extend as far towards the ITCZ as in the observations, similar as for the MCS on 10 March. The top of the declining lower moist layer roughly follows the observations. In the upper Hadley branch above $7 \mathrm{~km}$, i.e. the moist outflow, the ECMWF field generally tends to be too moist. The position and vertical extent of the ITCZ around -4 to $0^{\circ} \mathrm{S}$ seems to be captured correctly. The largest deviations again correspond to regions with most nonlinear development which can not be compensated by temporal interpolation.

\subsection{Transition to mid-latitudes on 14 March 2004}

The north section from 14 March (F030314-2) is characterized by stirring of moist tropical air with drier air from aloft

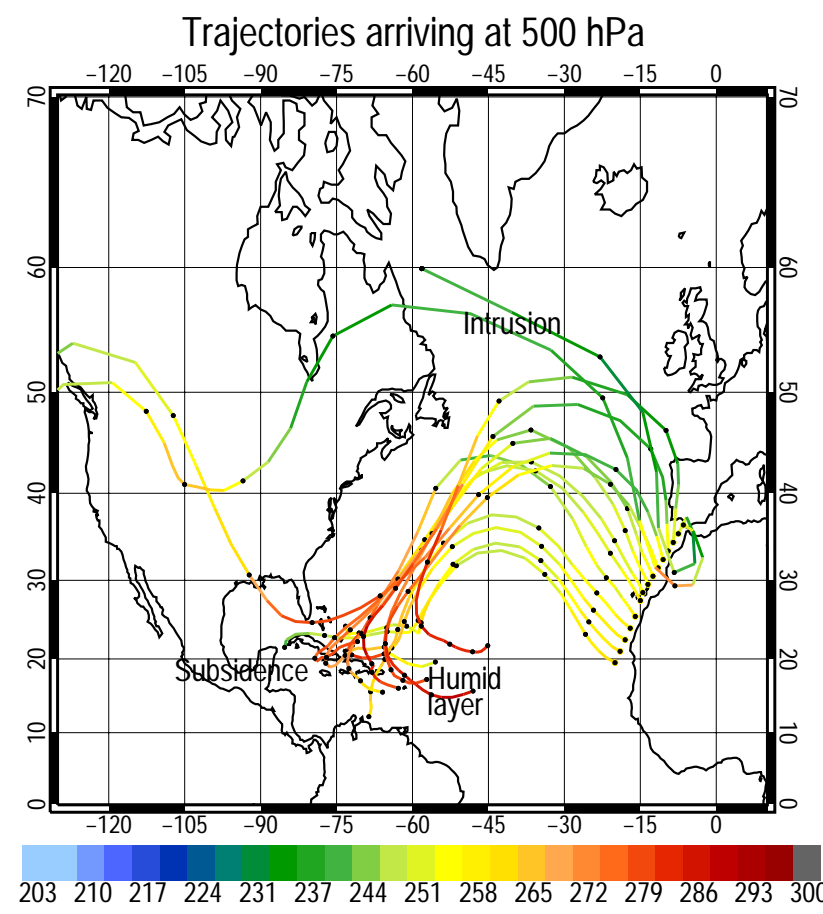

Fig. 5. As Fig. 4 but for back-trajectories arriving at $500 \mathrm{hPa}$ on 14 March 2004, 18:00 UT.

and from mid-latitudes (Fig. 3a, b). One prominent feature in both water vapour and aerosol is a narrow stratospheric intrusion sloping downward to $1.5 \mathrm{~km}$ from $35^{\circ} \mathrm{N}$ to $30^{\circ} \mathrm{N}$ with $q<0.2 \mathrm{~g} / \mathrm{kg}$ (unsmoothed DIAL data: $q_{\mathrm{min}} \approx 0.02 \mathrm{~g} / \mathrm{kg}$ in $4 \mathrm{~km})$ and enhanced $\mathrm{BSR}_{1064} \approx 3$. Back-trajectories, denoted "Intrusion" in Figs. 5 and 6 trace this air back to high altitudes over the north Atlantic. South of the intrusion moist air is found at mid-levels from the lower tropical troposphere, denoted as "Humid layer" back-trajectories in Figs. 5 and 6. While this air-mass comes down to the PBL near $30^{\circ} \mathrm{N}$, to the south there is a dry particle containing layer in-between the both, emerging from high altitudes over North America ("Descending UT Air" in Fig. 6). South of the intrusion, the "Humid Layer" extends up to $9 \mathrm{~km}$, and only south of $24^{\circ} \mathrm{N}$ declines below $500 \mathrm{hPa}$ where upper tropical air ("Subsidence" in Fig. 5) subsides to the flight section. The PBL depth grows from $1 \mathrm{~km}$ in the south to $2 \mathrm{~km}$ near $28^{\circ} \mathrm{N}$ where vertical mixing is evident at the tip of the intrusion. Inside the Gibraltar cyclone $\left(35-37^{\circ} \mathrm{N}\right)$ moist air, that has been advected over the Atlantic is spiralling up to $4 \mathrm{~km}$ ("LT Spain" trajectories in Fig. 6).

Most details of the relative complex WV distribution are reproduced by the ECMWF short-range FC. According to the relative difference field displayed in Fig. 3d, significant local deviations are found due to small spatial shifts in the presence of large gradients which typically reflect in adjacent moist and dry difference areas. The PBL FC is too moist and about half a km too shallow (Fig. $3 \mathrm{~d}$ : $<30^{\circ} \mathrm{N}, 1-2 \mathrm{~km}$ ). 
The intrusion FC is too steep and does not penetrate as much down $(\sim 1 \mathrm{~km})$ as observed in $\mathrm{WV}$ and $\mathrm{BSR}_{1064}$ near $30^{\circ} \mathrm{N}$. Large deviations again tend to be associated with larger nonlinearities in the $12 \mathrm{~h}$ development (Fig. 3d).

\section{Discussion}

Overall, the short-range forecasts of water vapour distributions along the flight sections across the tropical and subtropical Atlantic largely agree with the observations. The sections contain relatively small-scale baroclinic processes like stratospheric intrusion and large scale dynamical features like the Hadley cell. Locally large deviations are found due to spatial shifts in the presence of large gradients being an issue of small-scale in transport and resolution. But there are also discrepancies indicating deficits in modelling the hydrological cycle around the PBL, near meso-scale convection and in the upper troposphere.

On synoptic scales the humidity field closely reflects the diabatic transport as revealed by back-trajectories and the temperature history along the flow. While, flights F030310 and F030314-1 are dominated by organized extended convection, F030314-2 is characterized by a mixture of different adjoining air-masses. During transport these different airmasses stay coherent and are stirred rather than mixed so that large gradients are maintained. The agreement between IFS and DIAL fields is limited at smaller scales, due to the spatiotemporal resolution. For instance the entrainment to the PBL at the tip of the intrusion (Fig. $3 \mathrm{a}, 25^{\circ} \mathrm{N}-31^{\circ} \mathrm{N}$ ) is not indicated by the FC. Otherwise, the intense dynamic of the intrusion is captured remarkably well. Both the too large slope of the intrusion and the slightly different shape of the forecasted "Descending UT air" layer (Fig. 6; at 3$4 \mathrm{~km}$ in Fig. 3b, c) may be attributed to gradients perpendicular to the flight section (limiting the comparability of 3-D features based on a 2-D section only). Cross-flight-section air flow moves sub-gridscale 3-D features through the observation plane in an unpredictable manner. An attempt to identify this representativity effect is done by calculating the nonlinearity of the temporal development as shown by contours in Figs. 2d and 3d. More than 50\% deviation between the $t_{0} q$-values and the $t_{0-6 \mathrm{~h}}-t_{0+6 \mathrm{~h}}$ average hints to significant short-term variability within the 2-D section which is not contained in the analyses and thus cannot be captured by the forecasts. The largest small-scale model-observation differences are caused by this representativity effect. Correspondingly, the correlation between the ECMWF and DIAL WV distributions increases with the spatial scales, the coefficients being $r=0.69, r=0.92$ and $r=0.86$ for flights F030310, F030314-1 and F030314-2, respectively. Inversely, the 1- $\sigma$ standard deviation of the frequency distributions decreases with larger scales, being $\sigma \approx 66 \%, \sigma \approx 32 \%$ and $\sigma \approx 38 \%$ for the flights as before.

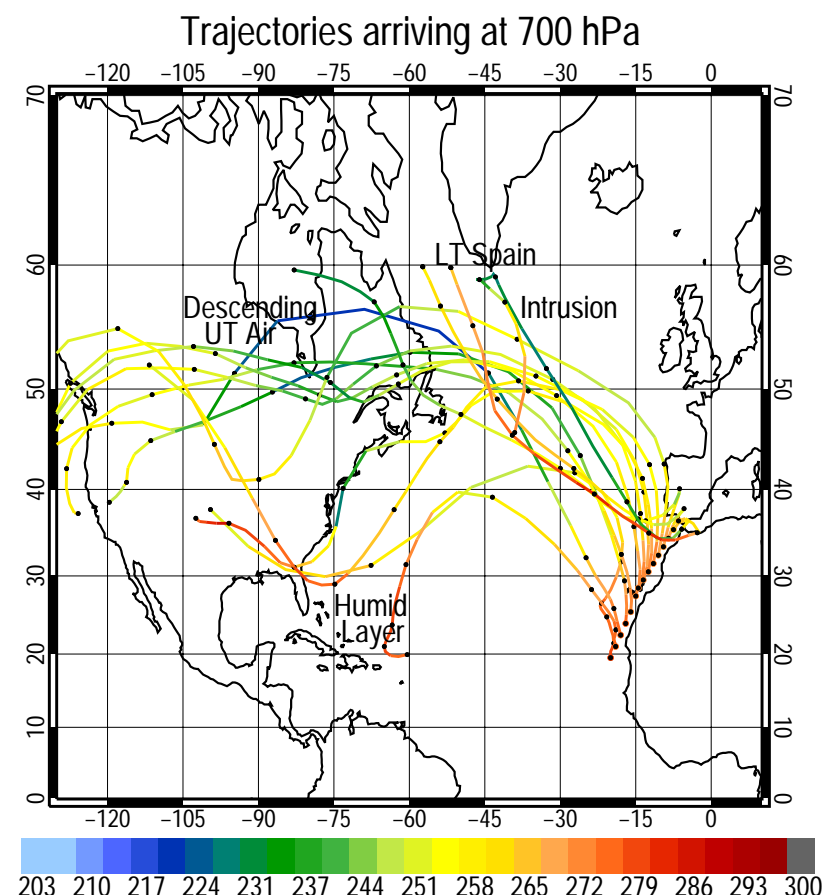

Fig. 6. As Fig. 4 but for back-trajectories arriving at $700 \mathrm{hPa}$ on 14 March 2004, 18:00 UT.

The PBL tends to be too moist in the forecasts, whereby we do not see to its lowest part with the DIAL where the crossed optical depth $\tau>0.9$. This may either indicate shortcomings in the parameterization of shallow convection and moist PBL processes in the IFS or be associated with the likewise underestimated PBL depth, being a matter of dilution, particularly over the ocean. A moist PBL bias and too low PBL depth in the ECMWF model are also reported by Hólm et al. (2002) using buoys and radiosondes over the Pacific and by Palm et al. (2005) based on space aerosol lidar (GLAS) data. Over the ocean the PBL depth and structure are primarily driven by the wind speed while the specific humidity is determined by the sea-air and the entrainment fluxes. As model surface wind and sea-air flux have been shown to agree closely with observations (e.g. Hólm et al., 2002), the entrainment of dry air from aloft could be too weak in the model as e.g. indicated near the intrusion during F030314-2 (cf. Sect. 3.4). Representativity errors discussed above are likely small since F030314-2 is approximately parallel to the flow at PBL top level and weak wind is indicated in Fig. 2c. F030310 took place under stable high pressure conditions where horizontal gradients are expected to be small. Against this, data assimilation e.g. from of the SSMI instrument may account for part of the difference. SSMI has the largest impact of all humidity data over the tropical/sub-tropical oceans and systematically adds moisture in the lower tropical troposphere (Andersson et al., 2006) as the background fields there are biased dry. Over land also radiosondes and synoptic 

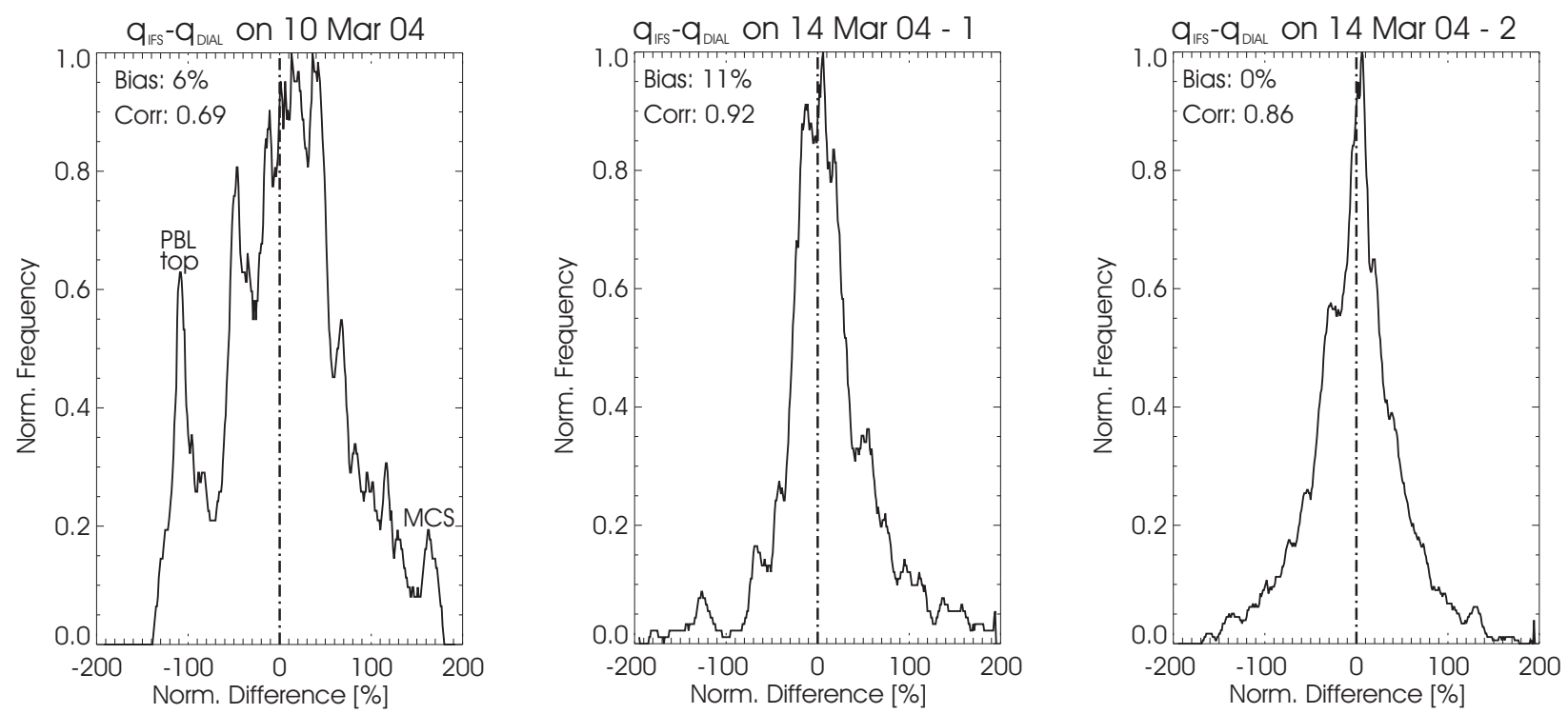

Fig. 7. Frequency distributions of normalized relative differences $100 \times\left(q_{\mathrm{ECMWF}}-q_{\mathrm{DIAL}}\right) /\left(q_{\mathrm{ECMWF}} / 2+q_{\mathrm{DIAL}} / 2\right)$ shown in Figs. $2 \mathrm{~d}$ and $3 \mathrm{~d}$ along the flights on 10 March (left) and 14 March 2004, 11:00-14:00 UT (middle) and 16:30-19:00 UT (right).

observations have significant impact to the analysis, but land is crossed only in the north parts of F030310 and F030314-2 where convection and baroclinicity strongly disturb the PBL.

Near both the MCS and the Hadley convective cells the forecast is too moist in the observed dry intermediate layers between convective in- and outflow, centred around $\sim 6 \mathrm{~km}$ and $\sim 7 \mathrm{~km}$, respectively. Similar observations are reported by Ovarlez and v. Velthoven (1997) from midlatitudes. Firstly, these systems consist of several sub-grid cells which are difficult to handle with the given resolution. Secondly, there is no satellite data available for assimilation below clouds and the coverage of radiosonde and synoptic data also does not capture the small spatiotemporal scales. In the model, either the turbulent mixing out of convective towers at mid-levels may be overestimated or the convection depth underestimated for part of the convection resulting in an unrealistic outflow at mid levels. The upper tropospheric anvil-outflow in the two tropical convection cases is also too moist in the ECMWF short-term forecasts and again hints to deficiencies in the convection parameterization (i.e. too much upward transport of WV) and its interaction with assimilated satellite data from SSMI, AIRS and GOES which are the main contributors around $300 \mathrm{hPa}$. Against this, the upper tropospheric humidity outside the tropics (F030314-2) varies around the observed range. Only the top of the intrusion is a bit too dry. Though the absolute WV amounts are small in the upper troposphere, this region is important for accurate radiative transfer calculations and cirrus cloud formation.

As unbiased water vapour analyses are a prerequisite for accurate modelling of the hydrological cycle, climate or specific processes, the model bias against absolutely cali- brated observations is of interest. Here it can be calculated as array-mean values of the normalized q-difference fields shown in Figs. 2d and 3d. The average biases of the ECMWF short-term forecasts with respect to the DIAL sections are $6 \pm 2 \%, 11 \pm 3 \%$, and $0 \pm 1 \%$ for the flights F040310, F040314-1 (11:00 UT) and F040314-2 (16:30 UT), respectively. The provided uncertainties are estimated from the sensitivity of the bias to the data which is excluded from the comparison. This is demonstrated by the frequency distributions of relative differences $\Delta q=100 \times\left(q_{\mathrm{ECMWF}^{-}}\right.$ $\left.q_{\text {DIAL }}\right) /\left(q_{\text {ECMWF }} / 2+q_{\text {DIAL }} / 2\right)$ shown in Figs. 7 a - c. On 10 March for example the bias is balanced by the moist deviation at mid-levels near the MCS $(\Delta q \approx+170 \%$ in Fig. 7a) and the dry deviation at the PBL top $(\Delta q \approx-110 \%)$. As regions with measurement artefacts (e.g. by saturated $\mathrm{H}_{2} \mathrm{O}-$ absorption lines) must be excluded, sub-cloud columns and much of the PBL are not taken into account. Including more data from the PBL would likely shift the bias up as would the inclusion of more data from below the MCS. However the "contaminated" data can be determined precisely, resulting in relatively small uncertainties. Admittedly, the representativity is limited to these specific atmospheric situations but on the other hand the observed features are typical for the low- and mid-latitude Atlantic region. The positive assessment of the ECMWF humidity fields has implications for other prognostic variables, too, since correct humidity distributions both require and permit overall accurate model fields.

\section{Summary}

Short-term water vapour forecasts with the ECMWF model system at T799/L91 spectral resolution are evaluated with 
airborne $\mathrm{H}_{2} \mathrm{O}$-DIAL observations over Brazil and from Brazil to south Europe in mid-March 2004. The 2-D alongflight sections across the tropical and sub-tropical Atlantic Ocean $\left(28^{\circ} \mathrm{S}-36^{\circ} \mathrm{N}\right)$ exhibit large humidity gradients with water vapour mixing ratios covering three orders of magnitude between $q \approx 0.01$ and $q>10 \mathrm{~g} / \mathrm{kg}$. Overall, the observed water vapour distributions are properly reproduced by the ECMWF model. The largest deviations from the observations are due to spatial shifts in the presence of large gradients. Over the ocean the PBL is too moist and too shallow. Near deep convection the mid-troposphere tends to be too humid in the model, indicating deficiencies in the convection parameterization and the data assimilation. Humid tendencies are also found in the upper troposphere under the influence of tropical convection. The observations and their differences to the model fields are discussed with respect to data assimilation, transport, representativity and model physics. Average biases are provided for the three flight sections $(6 \%, 11 \%$ and $0 \%)$, assuming that they are representative for a large range of low- and mid-latitude conditions. The model-observation correlation increases with the scales and amounts to $r=0.69, r=0.92$ and $r=0.86$ for the 10 March flight and the 1st and 2nd 14 March flights, respectively.

Acknowledgements. This work was funded by the ESA in the contract no. 10832/03/NL/FF and the European Community in the frame of the TROCCINOX project (EVK2-2001-00087).

Edited by: R. MacKenzie

\section{References}

Andersson, E., Hólm, E., and Thépaut, J. N.: Impact studies of main types of conventional and satellite humidity data, in: Proc. 3rd WMO Workshop on "The Impact of Various Observing Systems on Numerical Weather Prediction", Alpbach, Austria, 9-12 March 2004, edited by: Böttger, H., Menzel, P., and Pailleux, J., WMO/TD No. 1228, 32-44, 2004.

Andersson, E., Hólm, E., Bauer, P., Beljaars, A., Kelly, G. A., McNally, A. P., Simsons, A. J., Thépaut, J.-N., and Tompkins, A. M.: Analysis and forecast impact of the main humidity observing systems, ECMWF Technical Memorandum No. 493, ECMWF, Reading, 2006.

Bauer, P., Kelly, G., and Andersson, E.: SSM/I radiance assimilation at ECMWF, Proceedings at ECMWF/GEWEX workshop on "Humidity Analysis", Reading, U.K., 8-11 July 2002, 167-175, 2002.

Bengtsson, L., Hodges, K. I., and Hagemann, S.: Sensitivity of large scale atmospheric analyses to humidity observations and its impact on the global water cycle and tropical and extratropical weather systems in ERA40, Tellus, 56A, 202-217, 2004.

Chahine, M. T.: The hydrological cycle and its influence on climate, Nature, 359, 373-380, 1992.

Charlson, R. J. and Heintzenberg, J.: Aerosol forcing of climate, Report of the Dahlem Wokshop on Aerosol Forcing on Climate, Berlin 1994, John Wiley \& Sons, New York, 416 p., 1994.
Ehret, G., Hoinka, K. P., Stein, J., Fix, A., Kiemle, C., and Poberaj, G.: Low-Stratospheric Water Vapour Measured by an Airborne DIAL, J. Geophys. Res., 104(D24), S31 351-31 359, 1999.

Flentje, H., Dörnbrack, A., Ehret, G., Fix, A., Kiemle, C., Poberaj, G., and Wirth, M.: Water vapour heterogeneity related to stratospheric intrusions over the northern Atlantic revealed by airborne water vapour, J. Geophys. Res., 110, D03115, doi:10.1029/2004JD004957, 2005.

Forster, P. M. de F. and Shine, K. P.: Radiative forcing and temperature trends from stratospheric ozone depletion, J. Geophys. Res., 102, $10841-10855,1997$.

Gettelman, A., Forster, P. M. de F., Fujiwara, M., Fu, Q., Vömel, H., Gohar, L. K., Johanson, C., and Ammerman, M.: Radiation balance of the tropical tropopause layer, J. Geophys. Res., 109, D07103, doi:10.1029/2003JD004190, 2004.

Giver, L. P., Chackerian Jr., C., and Varanasi, P.: Visible and nearinfrared $\mathrm{H}_{2}{ }^{16} \mathrm{O}$ line intensity corrections for HITRAN-96, J. Quant. Spectrosc. Radiat. Transfer, 66(1), 101-105, 2000.

Hólm, E., Andersson, E., Beljaars, A., Lopez, P., Mahfouf, J.-F., Simmons, A., and Thépaut, J.-N.: Assimilation and modeling of the hydrological cycle: ECMWF's status and plans, ECMWF Technical Memorandum No. 383, ECMWF, Reading 2002.

Kärcher, B. and Solomon, S.: On the composition and optical extinction of particles in the tropopause region, J. Geophys. Res., 104, 27 441-27 459, 1999.

Kiehl, J. T. and Trenberth, K. E.: Earth's annual global mean energy budget, B. Am. Meteorol. Soc., 78, 197-208, 1997.

Kirk-Davidoff, D. B., Anderson, J., Hintsa, G. E. J., and Keith, D. W.: The effect of climate change on ozone depletion through changes in stratospheric water vapour, Nature, 402, 399-401, 1999.

Koop, T., Luo, B. P., Tsias, A. and Peter, T.: Water activity as the determinant for homogeneous ice nucleation in aqueous solutions, Nature, 406, 611-614, 2000.

Lawrence, M. G., Hov,Ö., Beekmann, M., Brandt, J., Elbern, H., Eskes, H., Feichter, H., and Takigawa, M.: The Chemical Weather, Environ. Chem., 2, 6-8, doi:10:1071/EN05014, 2005.

Leiterer, U., Dier, H., Nagel, D., Naebert, T., Althausen, D., Franke, K., Kats, A., and Wagner, F.: A correction method for RS80A Humicap profiles and their validation by Lidar backscattering profiles in tropical cirrus clouds, J. Atmos. Oceanic. Tech. (JTECH), 22, 18-29, 2005.

Manabe, S. and Weatherald, R.: Thermal equilibrium of the atmosphere with a given distribution of atmospheric humidity, J. Atmos. Sci., 24, 241-259, 1967.

Moreau, E., Lopez, P., Bauer, P., Tompkins, A. M., Janiskova, M., and Chevallier, F.: Variational retrieval of temperature and humidity profiles using rain rates versus microwave brightness temperatures, ECMWF Technical Memorandum No. 412, www. ecmwf.int, 2003.

Nash, J.: Review of test results on the accuracy of radiosonde relative humidity sensors, Proc. ECMWF/GEWEX workshop on "Humidity Analysis", Reading, U.K., 8-11 July 2002, 117-123, 2002.

Ovarlez, J. and van Velthoven, P.: Comparison of water vapour measurements with data retrieved from ECMWF analyses during the POLINAT experiment, J. Appl. Meteorol., 36, 1329-1335, 1997.

Palm, S. P., Benedetti, A., and Spinhirne, J.: Validation of ECMWF global forecast model parameters using GLAS atmo- 
spheric channel measurements, Geophys. Res. Lett, 32, L22S09, doi:10.1029/2005GL023535, 2005.

Poberaj, G., Fix, A., Assion, A., Wirth, M., Kiemle, C., and Ehret, G.: All-Solid-State Airborne DIAL for Water Vapour Measurements in the Tropopause Region: System Description and Assessment of Accuracy, Appl. Phys. B, 75, 165-172, 2002.

Pruppacher, H. R. and Klett, J. D.: Microphysics of clouds and precipitation, Dordrecht, Holland, D. Reidel Publ. Co., 976 p., 1997.

Rohrer, F. and Berresheim, H.: Strong correlation between levels of tropospheric hydroxyl radicals and solar ultraviolet radiation, Nature, 442, 184-187, doi:10.1038, 2006.

Shine, K. P. and Sinha, A.: Sensitivity of the earth's climate to height dependent changes in the water vapour mixing ratio, Nature, 354, 382-384, 1991.
Stohl, A., Haimberger, L., Scheele, M. P., and Wernli, H.: An intercomparison of results from three trajectory models, Meteorol. Appl., 8, 127-135, 2001.

Tompkins, A. M., Bechtold, P., Beljaars, A. C. M., Benedetti, A, Cheinet, S., Janisková, M., Köhler, M., Lopez, P., and Morcrette, J.-J.: Moist physical processes in the IFS: progress and plans, ECMWF Tech Memo., 452, 91 pp., 2004.

Tompkins, A. M., Gierens, K., and Rädel, G.: Ice supersaturation in the ECMWF integrated forecasting system, Q. J. R. Meteorol. Soc., 133, 53-56, 2007.

Wernli, H. and Davies, H. C.: A Lagrangian-based analysis of extratropical cyclones. I: The method and some applications, Q. J. R. Meteorol. Soc., 123, 467-489, 1997. 